\title{
What is CCZN-armalcolite? A crystal-chemical discussion and an ad-hoc incursion in the crichtonite-minerals group
}

\author{
Gavril SĂBĂU1* \& Augusta ALBERICO² \\ ${ }^{1}$ Geological Institute of Romania, Caransebeş 1, 012271 Bucureşti 32, Romania \\ 2 Dipartimento di Scienze Mineralogiche e Petrologiche, Via Valperga Caluso 35, 10125 Torino, Italy
}

Received March 2007; accepted September 2007

Available online 1 October 2007

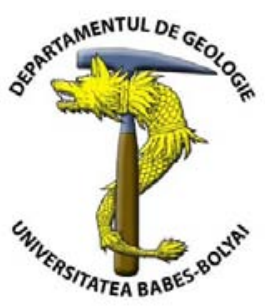

\begin{abstract}
The status of CCZN-armalcolite, commonly still believed to be a variety of armalcolite s.s., is questionable in view of partial evidence suggesting that it would represent a distinct phase, as initially claimed by its discoverers. Because of the rarity of the mineral, combined with its habitual small grain-size, no successful structural investigation could be undertaken so far. Therefore we attempted a chemical overview of existing and original data pertaining to CCZN-armalcolite. With the view of systematizing structure-composition relationships, we analyzed the topology of large cations - bearing close-packed oxides, while extending the nomenclature in use in order to accommodate further topologies. By using relevant chemical plots, a fair compositional match between CCZN-armalcolite and the crichtonite group minerals was demonstrated, as well as a chemical incompatibility with armalcolite. Stoichiometric crichtonite compositions and matching optical properties allowed identification of at least part of "CCZN-armalcolites" with the mineral loveringite of the crichtonite group. A detailed inspection of structure-composition relationships in crichtonites allowed an insight in their trends and range of chemical variation, as well as a comparison between them and a group of "CCZN-armalcolites" slightly differing from known crichtonites. These "CCZN-armalcolites" departing from normal chemical trends in crichtonites either represent an ordered variety of non-stoichiometric crichtonite or a new group of close-packed oxides. Their composition clustering around formula $\mathrm{AM}_{16} \mathrm{O}_{30}$ is temptingly consistent with an hypothetical structure intermediate between magnetoplumbites and crichtonites, based on close-packed stacking of layers made up by triangular clusters of octahedra, stuffed with large cations. A model of such a structure, not encountered so far in minerals, is outlined, displaying a hexagonal symmetry $\mathrm{P} \overline{3}$, with $a \approx 7.45 \AA$ and $c \approx 9.2 \AA$.
\end{abstract}

Key words: $\mathrm{CCZN}$-armalcolite, crichtonite group, loveringite, crystal structure, close-packed oxides

\section{INTRODUCTION: THE STATUS OF CCZN-ARMALCOLITE}

Armalcolite - $\left(\mathrm{Fe}^{2+}, \mathrm{Mg}\right) \mathrm{Ti}_{2} \mathrm{O}_{5}$ - is one of the mineral phases defined following its discovery on the Moon, from the samples collected during the first Apollo landing in Mare Tranquilitatis (Anderson et al., 1970). It is isostructural with pseudobrookite $\left(\mathrm{Fe}^{3+}{ }_{2} \mathrm{TiO}_{5}\right)$, a phase already known from terrestrial occurrences to form solid solutions towards both $\mathrm{Fe}^{2+} \mathrm{Ti}_{2} \mathrm{O}_{5}$ and $\mathrm{MgTi}_{2} \mathrm{O}_{5}$, with minor $\mathrm{Mn}, \mathrm{Al}$ and $\mathrm{Cr}$ (Ottreman and Frenzel, 1965). Subsequently to its discovery in lunar rocks, armalcolite was recognized in a number of terrestrial occurrences, especially in high-Ti alkaline effusive rocks and their xenoliths (Bowles, 1988; Brigatti et al., 1993; Grégoire et al., 2000 and refs. therein), but also in thermally metamorphosed crustal rocks (Hayob and Essene, 1995).

Lévy et al. (1972) and Brown et al. (1972) identified in the Apollo 14 samples a Ca-bearing Ti-, Fe-, $\mathrm{Cr}$ - and $\mathrm{Zr}$ oxide closely approaching the chemical formula of armalcolite. Brown et al. (1972) relied on the chemical similarity of this "phase X" with armalcolite in viewing it as a zirconian armalcolite. Yet, Lévy et al. (1972) pointed out that the phase in question displays a reflectivity spectrum essentially different from that of armalcolite, indicating a distinct mineral phase. More thorough investigation of the properties and structure of the new phase were prevented by the small grain size, an obstacle which also arose in subsequent findings of the compound. In addition to the initial occurrence in maria basalts and debris originating there from, the mineral was identified in samples taken from lunar highlands during the missions Apollo 15 (Haggerty, 1973), Apollo 16 (Brown et al., 1973), Apollo 17 (Steele, 1974) and Luna 20 (Reid et al., 1973). Almost unanimously considered a variety of armalcolite, it was termed "Zr-rich armalcolite" (Reid et al., 1973), "Cr-Zr - armalcolite" (Steele, 1974), or type 2 "Cr-Zr-Ca - armalcolite" in the threefold classification of lunar armalcolites by Haggerty (1973). The first terrestrial occurrence was reported as "Cr-Ca-(Nb, Zr) - armalcolite" (or CCNZA) from the Jagersfontein kimberlite (Haggerty, 1983), as an additional type to the compositional varieties of armalcolite previously identified. Haggerty (1991) further expanded the classification to include a "KCr-armalcolite" identified by Jaques et al. (1990) in the Argyle lamproite pipe. Accordingly, three subtypes of this armalcolite-like phase

\footnotetext{
* Correspondence: G. Săbău (g_sabau@yahoo.co.uk)
} 
emerge: (1) lunar Cr-Zr-Ca - "armalcolite", (2) kimberlitic CCNZ - "armalcolite" and (3) a K-bearing variety of previous, with varying $\mathrm{K} / \mathrm{Ca}$ ratios. All three of these varieties are characterized by $\mathrm{CaO}$ up to well above $3 \mathrm{wt} . \%$, while $\mathrm{Ca}$ is a large cation expectedly assuming low values in the armalcolite lattice. At the same time, smaller cations are present in variable amounts, suggesting rather loose substitution relationships than affiliation to categories assuming definite ratios among the substituents. It appears therefore that distinction of several CCNZ (or rather CCZN, Grégoire et al., 2000) - armalcolite types are excessive, considering also that no substantial evidence of it being an armalcolite is available altogether. The correlations among major cations $\left(\mathrm{TiO}_{2}\right.$ vs. $\mathrm{FeO}_{\mathrm{t}}+\mathrm{MgO}, \mathrm{Cr}_{2} \mathrm{O}_{3}$, and $\left.\mathrm{ZrO}_{2}\right)$ is indicated by Haggerty (1983) to be discriminant against chemically similar crichtonite-group minerals, as both armalcolite s. str. and CCZN-armalcolite display higher $\mathrm{TiO}_{2}$ contents (above 64 wt.\%). Yet the same chemical plots also clearly distinguish "CCZN-armalcolite" from normal low-Ca armalcolite (pure or $\mathrm{Cr}$ - and/or $\mathrm{Zr}$ - bearing).

Apart from those already mentioned, there are to our knowledge only two cited occurrences of terrestrial CCZNarmalcolite, both identified on account of its chemical composition alone: in harzburgitic xenoliths from the Kerguelen Islands (Grégoire et al., 2000) and in the Foltea garnet lherzolite, South Carpathians, Romania (Săbău et al., 1997). For the last mentioned occurrence, the armalcolite structure was not confirmed by SAED (Belluso et al., 1998), which instead yielded a pattern compatible with crichtonitegroup minerals.

Doubts about the true armalcolite nature of "CCZNarmalcolite" have been repeatedly expressed (e. g., Bowles, 1988; Grégoire et al., 2000), the most documented ones relying in the difficulty of some cations ( $\mathrm{Zr}$ and especially $\mathrm{Ca})$ to enter the armalcolite lattice in sufficient amounts (Hayob and Essene, 1995). On the other hand, high Ti contents identified in minerals of the crichtonite group (Wang et al., 1999) question the very suitability of Ti contents as a discriminant.

\section{LARGE CATIONS - BEARING CLOSE-PACKED OXIDES AND CCZN-ARMALCOLITES: A TOPOLOGICAL APPROACH}

The most salient feature of minerals classified as CCZNarmalcolites, is the presence of large cations (mostly $\mathrm{Ca}$ ) in quantities comparable with those in the crichtonite group minerals, thus implying a distinct (most probably highlycoordinated) reticular site hosting the large cations. Since no structure determination of CCZN-armalcolite is available, an estimation of the possibilities resulting from the analysis of known chemically-related structures and modes of occurrence is as yet the only possible way to provide an insight as to its actual nature.

With a single exception, all of the reported CCZNarmalcolites are related to rocks originating from the lunar or terrestrial mantle. Therefore, an inspection of large-cation bearing oxides from mantle rocks, especially the Ti-rich ones, is likely to offer some guidance in the evaluation of $\mathrm{CCZN}$-armalcolite. Large-cation bearing oxides from the mantle basically display three structural types, namely (a) the pyrochlore-type lattice, with large cations residing in structural channels of a rigid corner-sharing octahedral framework, and two structural types based on closest- packing of oxygen atoms: (b) a hollandite-type lattice with large cations also residing in structural channels (as in priderite, jeppeite, etc.), respectively (c) lattices in which the large cations substitute in the close-packed oxygen sites, like in the magnetoplumbite and crichtonite groups. Of these three variants, the last one is in agreement with the large cation contents of CCZN-armalcolite.

The basic topology of lattices based on closest-packing of oxygen and large cations substituting it can be generalized as follows:

1. The large cations assume a twelve-fold coordination, in two possible $\mathrm{AO}_{12}$ polyhedra, depending on the stacking sequence of the layers adjacent to the large cation. In case of cubic close-packing (CCP), the polyhedron is a cubeoctahedron like the A-site in cubic perovskite (Fig. 1a), while a hexagonal close-packing (HCP) generates a polyhedron like the $\mathrm{Ba}$-site in $\mathrm{BaTiO}_{3}$ (Fig. 1b). In each case the $\mathrm{AO}_{12}$ polyhedron shares its triangular faces with adjacent $\mathrm{MeO}_{6}$ octahedra (3 in each octahedral layer), being centred in a node of the oxygen sublattice.

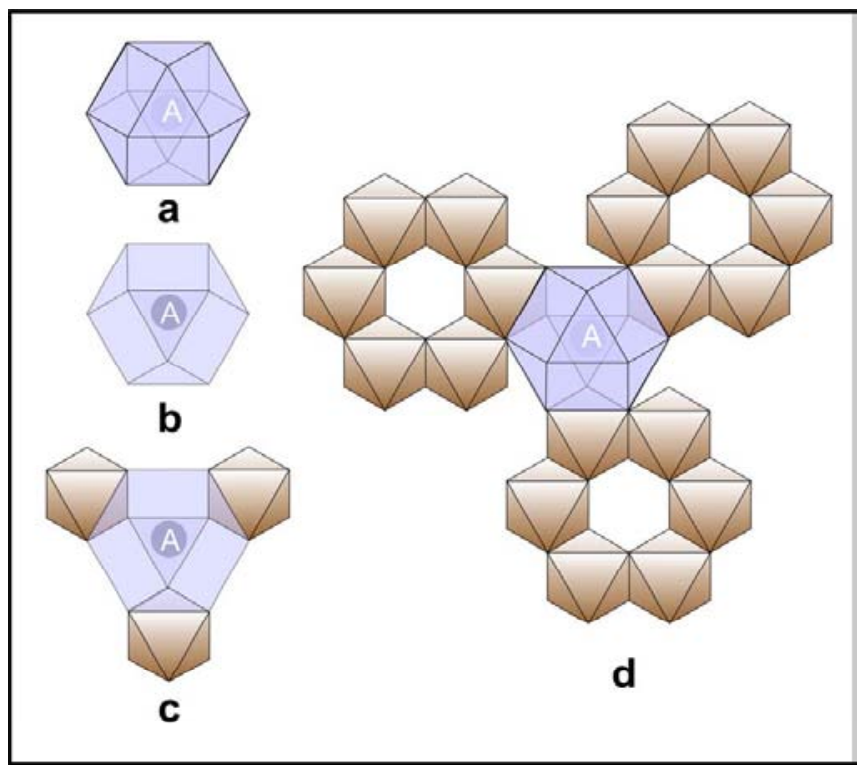

Fig. 1 .Large cation sites and their immediate surroundings in close-packed oxides. (a) Coordination polyhedron of a large cation in a CCP-based lattice, as in cubic perovskite

(b) Coordination polyhedron of a large cation in a HCP-based lattice, as in $\mathrm{BaTiO}_{3}$. (c) Large cations in the magnetoplumbite structure. (d) Large cations in the crichtonite structure.

2. The octahedra sharing faces with the A-site belong to clusters that form ternary bracelets (Moore, 1973) around it, while the clusters themselves have trigonal symmetry. From naturally occurring structures, magnetoplumbites contain $\mathrm{BaTiO}_{3}$-type A-sites and the adjacent clusters are formed by single octahedra (Moore et al., 1990) (Fig. 1c), resulting in $a_{\mathrm{hex}} \approx 2 * 2.88=5.76 \AA$ (considering an oxygen sublattice with $a=2.88 \AA$ - see Rouse and Peacor, 1968), while crichtonites display perovskite-type A-sites and hexagonal ring-shaped clusters of six octahedra (Grey and Lloyd, 1976) (Fig. 1d), with $a_{\text {hex }} \approx 2.88 \sqrt{ } 13 \AA=10.38 \AA$.

3. Sequences of two layers containing A-sites along the median plane are linked at either side with layers with nonsubstituted oxygens. The octahedra in the adjacent substituted and non-substituted layers are arranged according to a pattern - anti-pattern relationship, exemplified in Fig. 2. 


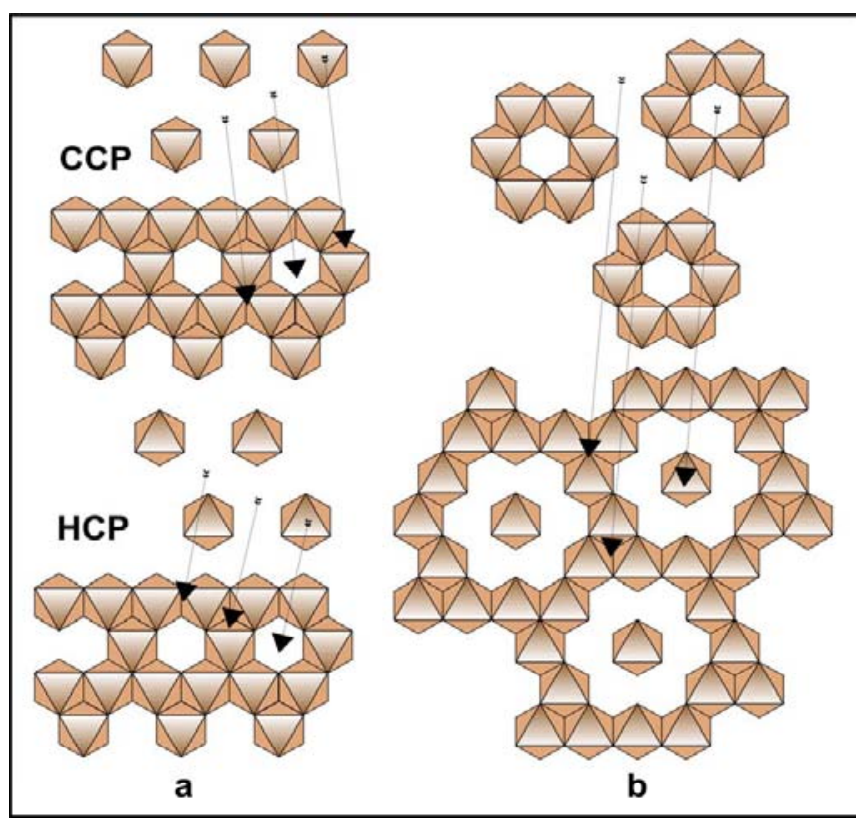

Fig. 2. Pattern - anti-pattern relationships between adjacent layers: (a) in magnetoplumbite (b) in crichtonite. Arrows indicate superposition relationships; upper layer (pattern) on top.

Additional tetrahedra usually located in the pattern layers, which contain fewer octahedra, connect the two layer types, linking three octahedral clusters and pointing to vertices in the anti-pattern layers.

Expanding the nomenclature currently used for closepacked oxides (Grey and Gatehouse, 1979), we identify the layers in the stacking sequence by the following notation: the $\mathrm{O}$ layers containing only octahedral cations are identified by a superscript index indicating the number of octahedra in the cluster, e. g., $\mathrm{O}_{1}$ for magneto-plumbite and $\mathrm{O}_{6}$ for crichtonite; the layers containing tetrahedra (Ti) are identified not only by the number of distinct tetrahedra attached to a cluster ( $i$. e. per unit cell), but also by the multiplicity of the cluster as in the previous case, and, if appropriate, by the nature of the substituent in the tetrahedral position(s) (A for an A-site, $\mathrm{M}$ for additional octahedra and $\mathrm{V}$ for vacancy), as the second subscript index. Thus, O, $\mathrm{T}_{1}$ and $\mathrm{T}_{2}$ of Grey and Gatehouse (1979) become $\mathrm{O}^{1}$, $\mathrm{T}^{1}{ }_{1 \mathrm{~V}}$ and $\mathrm{T}_{2}^{1}$, the stacking of magnetoplumbites can be described by the sequence $\mathrm{T}_{1 \mathrm{~A}}^{1}$ (h) $\mathrm{T}^{1}{ }_{1 \mathrm{~A}}$ (h) $\mathrm{O}^{1}$ (c) $\mathrm{T}_{2}^{1}$ (c) $\mathrm{O}^{1}$ (h), and that of crichtonites by $\mathrm{T}^{6}{ }_{1 \mathrm{~A}}$ (c) $\mathrm{T}^{6}{ }_{1 \mathrm{~A}}(\mathrm{~h}) \mathrm{O}^{6}(\mathrm{~h})$, where the lower-case letters in parentheses indicate the stacking type.

Alternative T-type layers of a six-membered pattern are $\mathrm{T}_{1 \mathrm{~V}}^{6}$ (self-explained) $\mathrm{T}_{0 \mathrm{AV}}^{6}$ (one vacancy and one $\mathrm{A}$ cation instead of tetrahedra), and $\mathrm{T}_{0 \mathrm{~A}}^{6}$ (both tetrahedra replaced by an A-centred polyhedron. The sequence $T_{i A}$ (c) $\mathrm{T}_{\mathrm{iA}}$ implies a perovskite-type A-site, while $\mathrm{T}_{\mathrm{iA}}$ (h) $\mathrm{T}_{\mathrm{iA}}$ corresponds to a $\mathrm{BaTiO}_{3}$ - type one.

Though not identified so far, derivatives of these basic structures achieved either by different layers (e. g. $\left.\mathrm{T}^{3}-\mathrm{O}^{3}\right)$ or by different stacking sequences might prove important in minerals, as it is the case for largecation-free closest packed oxides (Grey and Gatehouse, 1979).

Changes in the structure of the layers and in the stacking sequence reflect themselves in both the structure and the composition of the mineral phases, allowing thereby a possibility of tracking these changes by evaluating the chemical compositions.

\section{RELATIONSHIPS WITH KNOWN MINERAL SPECIES: LINGUISTIC WITH ARMALCOLITE S. STR. AND COMPOSITIONAL WITH CRICHTONITE-GROUP MINERALS}

All available analyses of lunar and terrestrial CCZNarmalcolites were recalculated to $\mathrm{A}=1$ basis, in order to be compared with large-cation bearing Ti-rich oxides with determined structure and composition. After normalization, the recast formula yielded for the majority of analyses $\mathrm{A} / \mathrm{M} / \mathrm{O}$ ratios close to the ideal crichtonite formula, $\mathrm{AM}_{21} \mathrm{O}_{38}$. For comparison purposes, an extensive number of published analyses of crichtonite-group minerals were plotted along with CCZN-armalcolites in an $\mathrm{O}$ vs. $\mathrm{M}$ diagram (Fig. 3), including all known species defined by the classical A-cation nomenclature $(\mathrm{Pb}-$ senaite, $\mathrm{Sr}-$ crichtonite, REE - davidite, $\mathrm{Ca}$ - loveringite, $\mathrm{Na}$ landauite, $\mathrm{K}$ - mathiasite, $\mathrm{Ba}$ - lindsleyite), intermediate terms, dessauite-(Y) of Orlandi et al. (1997), gramaccioliite(Y) (Orlandi et al., 2004), cleusonite (Wülser et al., 2005), the Re-bearing Sr, Pb - titanate of Sarp et al. (1981) and the analysis repeated by Orlandi et al. (2004) on allegedly the same material as the latter, yielding a different and Re-free composition. The plotted analyses encompass all occurrence types of the crichtonite-group minerals:

- in ultramafic xenoliths from the Garnet Ridge diatreme, Arizona (crichtonite, loveringite, Wang et al., 1999), nodules in kimberlites at De Beers, Bultfontein, Jagersfontein, Kolonkwanen (Haggerty et al., 1983 lindsleyite, mathiasite, LIMA; Gatehouse et al., 1983 mathiasite);

- in spinel cumulates from the meta-ophiolites at northern Apennines (loveringite - Cabella et al., 1997);

- in layered intrusions of the Bushveld Complex (Cameron, 1978 - loveringite); the Laouni Complex, Hoggar (Lorand et al., 1987 - loveringite, including analyses with excess Ca); at Koitelainen, Finland (Tarkian and Mutanen, 1987 loveringite); Jimberlana, Australia (Kelly et al., 1979 loveringite, Gatehouse et al., 1978 - loveringite, davidite-(La), Campbell and Kelly (1978) -loveringite); the Burakovsky intrusion in Karelia (Barkov et al., 1994 - loveringite);

- in hydrothermally altered rocks including Alpine-type veins in the Pandora Prospect, Arizona (Gatehouse et al. 1979 davidite), Radium Hill and Olary, South Australia (davidite Gatehouse et al., 1978; Gatehouse et al., 1979), the Diamantina region, Minas Gerais, Brazil (senaite - Rouse and Peacor, 1968; Grey and Lloyd, 1976; Grey et al., 1976), in the Alps (Grey et al., 1976 - crichtonite, Kelly et al., 1979; Orlandi et al. 1997 dessauite-(Y), Sarp et al., 1981; Stalder and Bühler, 1987 senaite-crichtonite-davidite solid solutions, including a "davidite" with very low occupancy of the A-site), gramaccioliite-(Y), cleusonite - ref. cit.).

In order to circumvent difficulties arising from unknown iron speciation as determined with the microprobe, analyses were recalculated for both divalent and trivalent iron, to each one corresponding a pair of points offset along the ordinate proportionally with the iron content. All cations with ionic radii equal with or larger than $1 \AA$ in octahedral coordination were assigned to the higher-coordinated A site. Following the suggestion of Gatehouse et al. (1979), the possibility of $\mathrm{Ce}$ incorporation as $\mathrm{Ce}^{4+}$ in the $\mathrm{M}(1)$ site was considered by testing the effect of different assignments of $\mathrm{Ce}$ on populations with variable Ce contents from the same occurrence. 


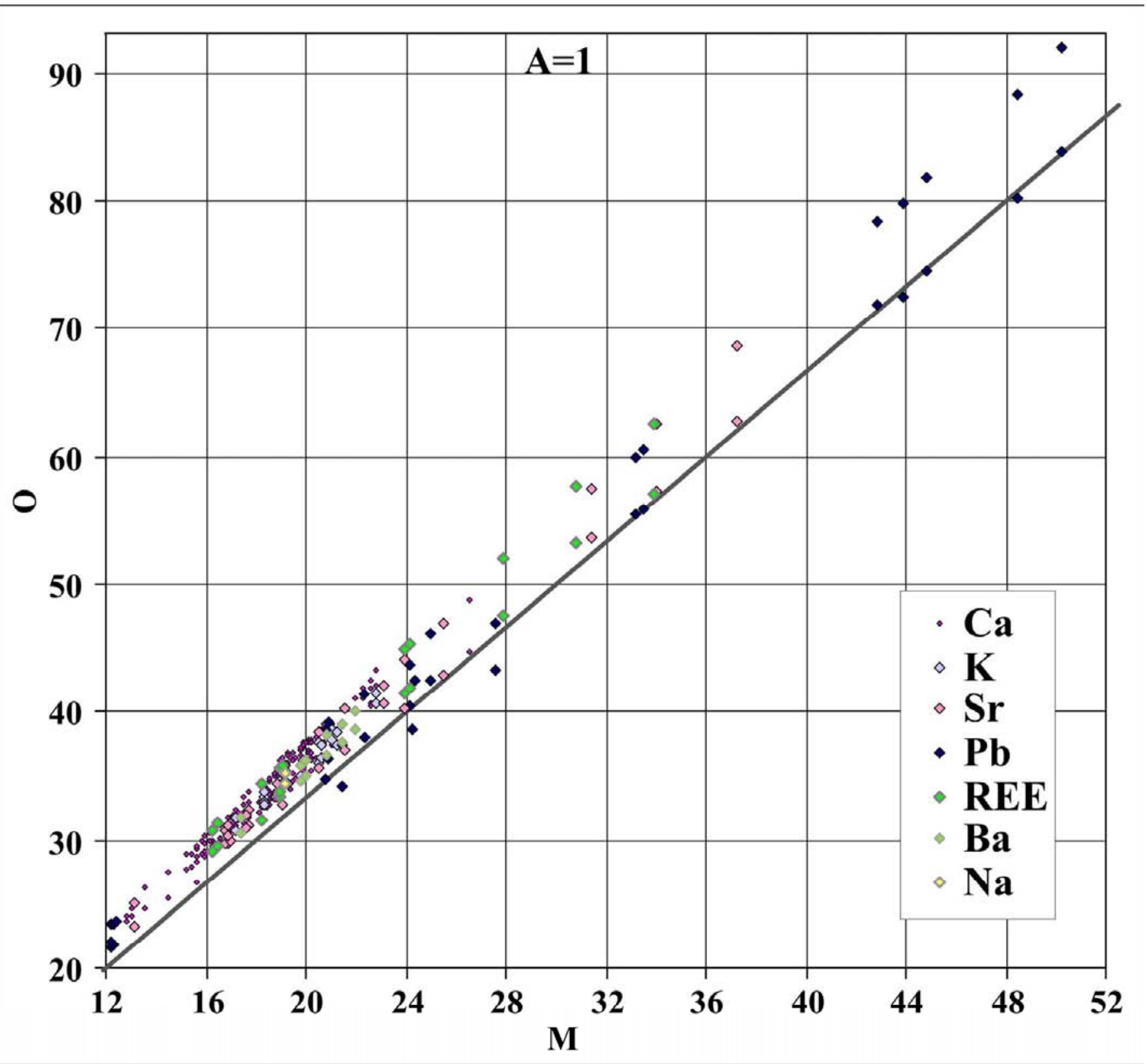

Fig. 3. Plot of oxygen $(O)$ versus small and intermediate cations $(M)$ of "CCZN-armalcolites" along with crichtonite minerals. Plot values normalized to large cations $A=1$. Each point is plotted twice considering both $\mathrm{Fe}=\mathrm{Fe}^{2+}$ and $\mathrm{Fe}=\mathrm{Fe}^{3+}$. Thick diagonal line: A/M ratio corresponding to armalcolite. Symbols distinguish among dominant large cation.

It resulted that $\mathrm{Ce}$ is likely to prevalently assume a higher charge and a lower coordination in kimberlitic crichtonites, while in those from layered intrusions $\mathrm{Ce}$ is mostly trivalent and enters the A-site. Crichtonites from veins were assumed to contain only octahedrally coordinated $\mathrm{Ce}^{4+}$, in agreement with a higher oxidation state indicated by prevalent $\mathrm{Fe}^{3+}$ reported from such occurrences (e.g., Grey et al., 1976). Both U and V were considered tetravalent in all analyses, inasmuch as their oxidation state bears little effect on the $\mathrm{A} / \mathrm{M} / \mathrm{O}$ ratio. The plotted data (Fig. 3) display a wide scatter away from the theoretical crichtonite formula, nevertheless along an array assuming a constant $\mathrm{M} / \mathrm{O}$ ratio. The array is clearly located to the left from the $\mathrm{O}=5 / 3 \mathrm{M}$ line corresponding to armalcolite, thereby indicating a lower $\mathrm{M} / \mathrm{O}$ ratio of both crichtonites and CCZN-armalcolites plotted. Along the array, a tendency of the points to group in clusters is noticeable. Crichtonites completely cover the compositional field of CCZN-armal- colites and extend significantly beyond it. The same features, including the departure from the armalcolite line, are also noticeable in the $\mathrm{A}+\mathrm{M}$ vs. $\mathrm{O}$ plot covering only the field of Ca-dominant terms (Fig. 4). $\mathrm{CCZN}$-armalcolites are indistinguishable from crichtonites, most of them plotting very close to the theoretical $\mathrm{AM}_{21} \mathrm{O}_{38}$ point. Taking also into account that the unusual reflectance spectrum of Lévy et al. (1972), strikingly different from armalcolite, closely matches the characteristic loveringite spectra of Tarkian and Mutanen (1987), as well as LIMA quantitative reflectance data of Haggerty et al. (1983), it becomes obvious that lunar $\mathrm{CCZN}$-armalcolite is in fact loveringite. It becomes also almost certain that the $\mathrm{KCr}$-armalcolite from the Argyle kimberlite (Jaques et al., 1990) is an intermediate term between loveringite and mathiasite. The other terrestrial CCZN-armalcolites also plot in Fig. 4 in clusters that contain crichtonite-type minerals confirmed by structure refinements or diffraction data, though displaying 
differences from the ideal stoichiometry. Thus, the problem has shifted from the question as to the nature of "CCZNarmalcolite" to the more specific question whether all "CCZN-armalcolites" are crichtonite-group minerals or not.
Therefore an analysis of the basic structure of crichtonites and its alterations documented by structure refinements may prove useful in evaluating the remaining "CCZNarmalcolites".

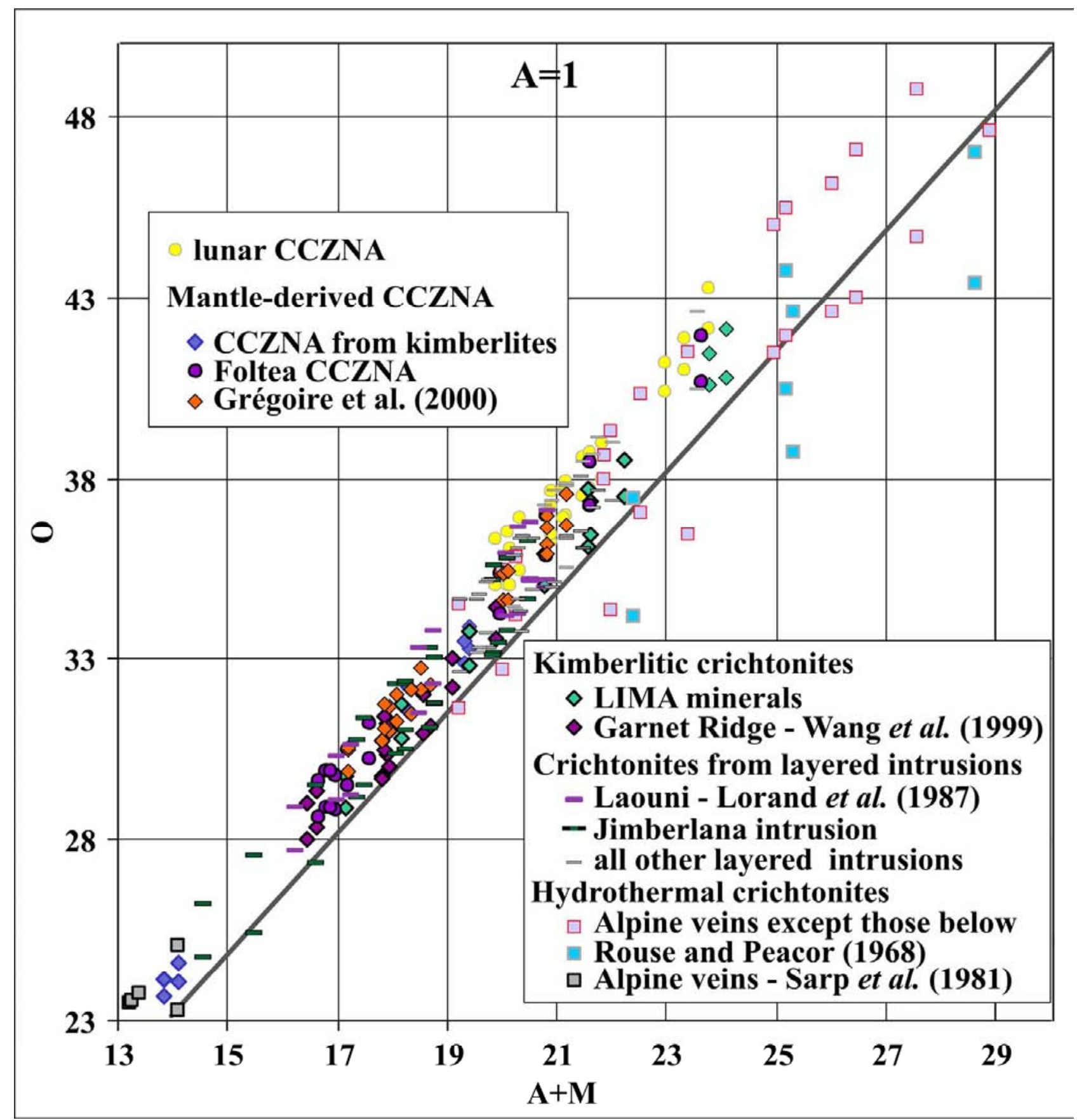

Fig. 4. $O$ vs. $A+M$ plot of crichtonites and "CCZN-armalcolite” covering the range of Ca-dominant crichtonites (loveringites). Plot data distinguished by occurrence type, but also by reference or location if needed.

THE CRICHTONITE-GROUP MINERALS:

CRYSTAL CHEMISTRY AND POSSIBLE SOURCES OF NON-STOICHIOMETRY

Though discovered more than two centuries ago, crichtonite group minerals proved for a long time deceptive to structural investigations, mainly due to frequent fine-scale twinning, but also because of metamictization of radioactive varieties. The characteristic layout of the precession pattern of most crichtonites (Pabst, 1961) results from twinning of the two enantiomorphs of the crichtonite structure (space group $\mathrm{R} \overline{3}$ ). Through basal twinning, a supercell with $\mathrm{a}_{\mathrm{hex}}=$
$2.88 *(\sqrt{3})^{2}=37.44$ (see Pabst in Rouse and Peacor, 1968) is achieved, initially thought to be the actual a axis of crichtonites (Hey et al., 1969).

After the first successful structure determination of the $\mathrm{Pb}$ end-member senaite (Grey and Lloyd, 1976), other minerals of the crichtonite group were found to have an identical structure (crichtonite - Grey et al., 1976; loveringite - Gatehouse et al., 1978; davidite - Gatehouse et al., 1979), corresponding to the formula $\mathrm{AM}_{21} \mathrm{O}_{38}$. The stacking sequence, atom labels and both hexagonal and rhombohedral cell are outlined in Fig. 5a. 


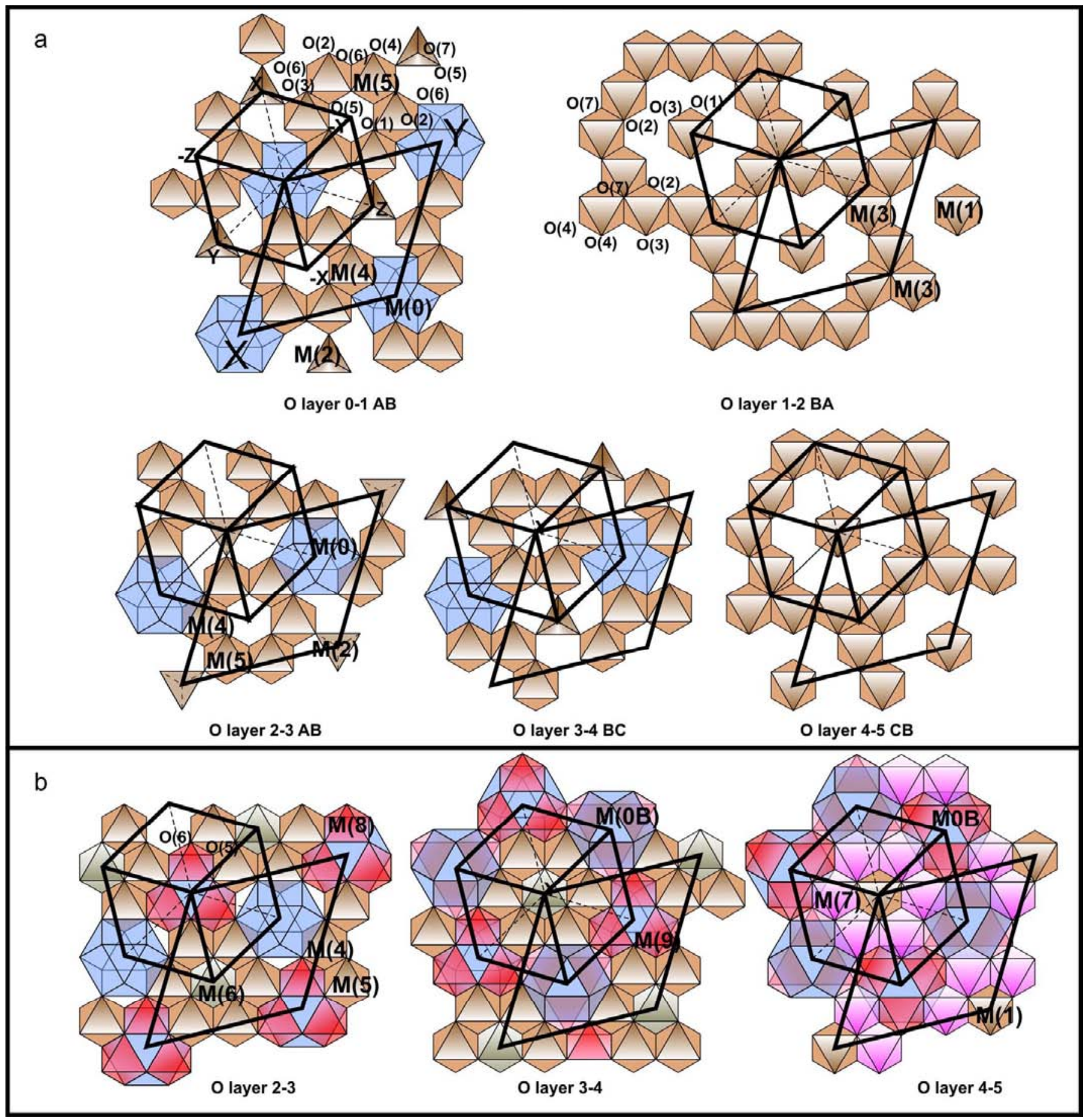

Fig. 5. Crystallographic sites and stacking sequence in normal and modified crichtonite. Hexagonal and rhombohedral cell are outlined and atoms labeled. Below each metal layer, oxygen layers are numbered, starting from origin (zero) layer; oxygen stacking also figured. (a) The first five metal layers of the crichtonite stacking sequence, extending over more than half (5/9) of the height of the unit cell. (b) The three last layers of previous modified to include extra cation sites discussed in text.

Departures from ideal stoichiometry of some analyses of crichtonite-group minerals were tentatively explained by additional $\mathrm{M}$ sites (Grey et al., 1976, referring to $\mathrm{Fe}^{2+}$ senaites of Rouse and Peacor, 1968), or substitution of $\mathrm{O}(7)$ by additional large cations and/or vacancies, also resulting in vacancies in the adjacent $\mathrm{M}(2)$ and $\mathrm{M}(3)$ sites (Gatehouse et al., 1978). In this case, the 36 nodes per cell of the closepacked lattice not lying on the trigonal axis would be always occupied by oxygen, while the three remaining nodes would display alternative occupation by large cations or vacancies.

The generalized formula $A_{3-x} \square_{x} M_{y} O_{36}$ proposed by the cited authors fails to cover both stoichiometric crichtonite minerals and intermediate terms displaying partial occupation of the $\mathrm{O}(7)$ and $\mathrm{M}(2)$ sites, and therefore should be reformulated to $A_{3-\mathrm{x}-\mathrm{z}} \square_{\mathrm{x}} \mathrm{M}_{\mathrm{y}} \mathrm{O}_{36+\mathrm{z}}$. The possibility of fivefold coordinated cations sharing faces with the $\mathrm{AO}_{12}$ polyhedra to compensate for $\mathrm{M}(3)$ vacancies is also envisaged. Vacancies residing on the trigonal axis would explain both relatively low measured densities and low A occupancies frequent in davidites, as for instance reported by Pabst (1961). Gatehouse et al. (1979) re-discuss the origin of low densities and consequently low calculated oxygen numbers in Pabst's (1961) davidites, reaching to the alternative conclusion that slackening of the structure during 
metamictization be responsible. At least some of the grains investigated by Pabst (1961) show indeed a density increase during the reversal of the process by heating. The refinement of mathiasite (Gatehouse et al., 1983) yielded an additional site $\mathrm{M}(6)$ occupying the centre of the hexagonal ring in the $\mathrm{T}^{6}{ }_{1 \mathrm{~A}}$ layer. The authors considered it in connection with an excess of large cations substituting in the $\mathrm{O}(7)$ position, capped by the new $\mathrm{M}(6)$ site (Fig. 5b), though in the structural refinement neither was this substitution accounted for in the assignment of the large cations, nor by the vacancies due in $\mathrm{M}(3)$ or evidence for additional metal sites resulting from relocation of $\mathrm{M}(3)$ cations. In order to preserve consistency in labeling all other sites with the previously published assignments, we shall identify the cation-site resulting from replacement of $\mathrm{O}(7)$ as $\mathrm{M} 0 \mathrm{~B}$ (Fig. 5b).

The structural investigation yielding the largest number of cation positions is that of Orlandi et al. (1997) for the new mineral dessauite. In addition to previously proposed position $\mathrm{M}(6)$, their structural refinement resulted in the octahedral site M(7) (cf. Grey et. al, 1976), the octahedral site $\mathrm{M}(8)$, which would replace site $\mathrm{M}(0)$ or share faces with it (in which case the coordination number would be reduced to 5), and the site $M(9)$ in square pyramidal coordination (Fig. 5b). It is to note that the presence of penta-coordinated $\mathrm{M}(9)$ implies the existence of $\mathrm{M}(0 \mathrm{~B})$ as well.

As seen from Fig. 5b, the large cations in amounts exceeding stoichiometric values in crichtonite group minerals can only be assigned to site $\mathrm{M}(0 \mathrm{~B})$, incompatible with $\mathrm{O}(7), \mathrm{M}(2)$ and $\mathrm{M}(3)$. In order to articulate $\mathrm{BaTiO}_{3}$-like $\mathrm{M}(0 \mathrm{~B}) \mathrm{O}_{12}$ cages, $\mathrm{M}(7)$ octahedra are needed. To maintain cell dimensions and symmetry, $\mathrm{M}(7)$ octahedra are to form hexagonal rings centered on $\mathrm{M}(1)$ and share faces with $\mathrm{M}(4)$ and $M(5)$ located in the adjacent layers. Such a configuration results in an octahedral pattern of the thus modified " $\mathrm{O}_{\mathrm{A}}^{6}$ " layer indistinguishable from that of the adjacent $\mathrm{T}^{6}{ }_{0 \mathrm{~A}}$ layers, with $\mathrm{M}(7)$ standing for $\mathrm{M}(4)$ and $\mathrm{M}(5)$, and $\mathrm{M}(1)$ for $\mathrm{M}(6)$, that leads to the composition $\mathrm{A}_{3} \mathrm{M}_{20} \mathrm{O}_{36}$, or $\mathrm{A}_{3} \mathrm{M}_{19} \mathrm{O}_{36}$ if both $\mathrm{M}(1)$ and $\mathrm{M}(6)$ are only half occupied. In this configuration, all octahedra in rings should share faces with two other octahedra in the adjacent layer, thereby rendering it highly improbable, while along the ternary axes two face sharing octahedra alternate with two basal-face sharing $\mathrm{AO}_{12}$ polyhedra. The presence of all sites refined by Orlandi et al. (1997) is therefore only possible by partial occupancy, associated to a high amount of structural disorder both within and across the layers, and is not expected to host substantial extra large cations. Nevertheless, the mineral described by Sarp et al. (1981) is proven by Roentgen diffraction to possess a crichtonite-type structure, and at the same time contains extensive amounts of excess large cations. A more feasible possibility, so far not confirmed by structure refinements, is in this case articulation of the $\mathrm{M}(0 \mathrm{~B}) \mathrm{O}_{12}$ cages to the adjacent layers by $\mathrm{M}(9)$ square pyramids, with extensive $\mathrm{M}(7)$ vacancies. $\mathrm{M}(9) \mathrm{O}_{5}$ polyhedra would consequently share only edges with octahedra and the basal face with $\mathrm{M}(0 \mathrm{~B}) \mathrm{O}_{12}$ polyhedra, thus implying more reasonable cation-cation distances.

Other possibilities of departure from the ideal crichtonite formula, not proven so far, are (1) a different stacking sequence containing the same layers or rather their slightly altered derivatives, or, alternately, (2) a significantly different ordering of the cations inside the layers. Both alternatives would induce substantial alteration of the space group and/or cell dimensions as compared to those of crichtonite-group minerals. Different stacking sequences can result in both higher and lower $\mathrm{A} / \mathrm{M}$ ratios. For instance, excess A cations can be hosted in additional modified tetrahedral layers $\mathrm{T}_{0 \mathrm{~A}}^{6}$, with a stacking sequence $\mathrm{T}^{6}{ }_{1 \mathrm{~A}}$ (c) $\mathrm{T}^{6}{ }_{0 \mathrm{~A}}(\mathrm{c}) \mathrm{T}^{6}{ }_{1 \mathrm{~A}}(\mathrm{~h}) \mathrm{O}^{6}(\mathrm{~h})(=\mathrm{c} 2 \mathrm{~h} 2 .$.$) , the formula normalised to$ $\mathrm{A}=1 \mathrm{AM}_{13.5} \mathrm{O}_{25}$, but with $c_{\text {hex }} \approx 2.3 * 12=27.6 \AA$. Conversely, tetrahedral layers containing no A cations can enter the normal stacking sequence $\mathrm{T}^{6}{ }_{2}$ (c) $\mathrm{T}_{2}^{6}$ (h) $\mathrm{O}^{6}(\mathrm{~h})$, evolving towards end-member formula $\mathrm{M}_{23} \mathrm{O}_{39}$ (Grey et al., 1976) compound $\mathrm{M}_{15} \mathrm{O}_{26}$, but with a different stacking sequence $\left.\mathrm{T}^{6}{ }_{2}(\mathrm{~h}) \mathrm{O}^{6}(\mathrm{~h}), c_{\mathrm{hex}} \approx 2.3 * 2=4.6 \AA\right)$, or may form a stacking sequence $\mathrm{T}^{6}{ }_{2}$ (h) $\mathrm{O}^{6}$ (h) $\mathrm{T}^{6}{ }_{1 \mathrm{~A}}$ (c) $\mathrm{T}^{6}{ }_{1 \mathrm{~A}}$ (h) $\mathrm{O}^{6}$ (h) (= ch4..), with formula $\mathrm{AM}_{36} \mathrm{O}_{64}$ and $c_{\text {hex }} \approx 2.3 * 15=34.5 \AA$. Such deviations from normal layer compositions and stacking sequences may possibly be incorporated in the structure as stacking errors, but their compositional effect would be limited if the overall cell dimension and symmetry are to be preserved.

\section{UNIT-CELL CONTENTS IN NATURAL CRICHTONITES AND THE “CCZN-ARMALCOLITE" FORMULA}

In order to evaluate the structure-composition relationships of the minerals plotted in previous figures, all analytical values were renormalized on a crystal-chemical basis, according to the cell contents of crichtonite, i. e., $\mathrm{A}+\mathrm{O}$ $=39-\mathrm{x}$. The $\mathrm{x}$ variable represents vacancies in $\mathrm{M}(0)$ as resulting from the site-assignments of cations and its effect is negligible for A values exceeding 0.75 p.f.u. The recalculated values were projected in an A vs. M plot in order to identify chemical trends in crichtonites and their relationships with "CCZN-armalcolites", especially those not matching theoretical crichtonite formulas.

Fig. $6 \mathrm{a}$ is a plot of the compositions of crystals used for structure determination of the species in the crichtonite minerals group, together with the chemical shifts expected for the structural alterations described above. Since there is but limited agreement in the published papers as to the assignment of cations with intermediate radii $(\mathrm{Ca}, \mathrm{REE}, \mathrm{U}$, Th) among the $M(0)$ and $M(1)$ sites, the $A M$ vector was also represented, in order to test possible erroneous site allocation during our recalculation of crystal-chemical formulae. Each point was calculated for both $\mathrm{Fe}=\mathrm{Fe}^{2+}$ and $\mathrm{Fe}=\mathrm{Fe}^{3+}$. Surprisingly, dessauite of Orlandi et al. (1997) plotted closest to the theoretical crichtonite formula, despite the fact that its structure refinement provided most of the "unconventional" cation sites. This feature may be related to disordered crystallization also known, for instance, to frequently occur in adularias from Alpine veins. It is to note that for A-deficient crichtonites it is impossible to discern among the chemical shifts associated to three of the trends represented in Fig. 6, namely two different ways of introduction of $\mathrm{T}_{2}^{6}$ in the stacking sequence, and possible misallocation of A cations to the M(1) site. Fortunately, as seen below, this indetermination bears no effect on the analyses discussed.

In Figs. $6 \mathrm{~b}$ and $\mathrm{c}$ all analyses are plotted together with the minerals for which structural refinements exist and the above-discussed chemical trends for end-compositions calculated with $\mathrm{Fe}^{3+}$ (Fig. 6a) and $\mathrm{Fe}^{2+}$ (Fig. 6b) respectively. Although for most of the analyses the prevalent iron speciation can be reconstructed from existing chemical 
analyses or estimated by comparison of totals calculated on basis of both oxidation states, and occurrence types, we preferred to consider both iron oxidation states in order to trace differences inside individual populations and to more accurately discuss populations with intermediate oxidation degree. Some regularities emerge from Fig. 6.
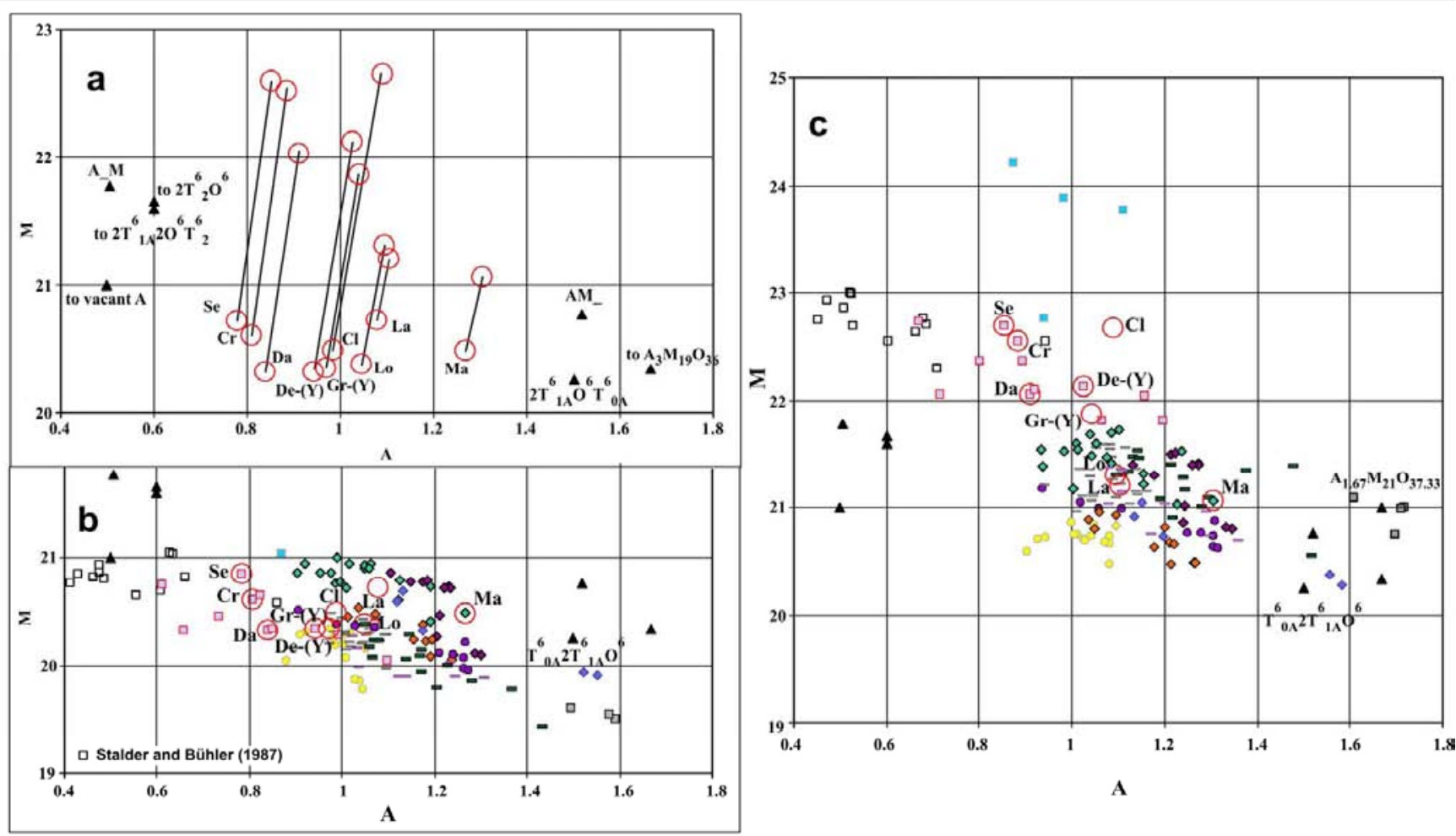

Fig. 6. $M$ vs. A plot normalised to the crichtonite unit cell content (39 anion positions). (a) Plot of the reference data (minerals on which structure refinements have been carried out), with outline of the chemical vectors discussed in text. Mineral name abbreviations contain the first two letters of the species. Lines connect the two recalculations of the formula considering both oxidation states of iron.

The compositional points lay along the line, according to the actual $\mathrm{Fe}^{2+} / \mathrm{Fe}^{3+}$ ratio. (b) Projection of all values recalculated for Fe $=\mathrm{Fe}{ }^{3+}$. Analyses and symbols are as in Fig. 4, augmented with data outside the range represented in Fig. 4.

(c) Projection of all values recalculated for $\mathrm{Fe}=\mathrm{Fe}^{2+}$.

1. There is a conspicuous grouping around the theoretical $\mathrm{AM}_{21} \mathrm{O}_{38}$ point, achieved with variations according to occurrence or occurrence type. The analyses from the Moon, part of those from nodules in the Kerguelen basalts and the Foltea garnet lherzolite appear to be $\mathrm{Fe}^{2+}$ compositions. The lunar "CCZN-armalcolites" are slightly shifted towards the origin because they contain some $\mathrm{Ti}^{3+}$ (Bowles, 1988) not accounted for, as well as partly because a few of the analyses (Steele, 1972; Steele and Smith, 1974) also display low totals, instead of high ones as expected when recalculated with $\mathrm{TiO}_{2}$, implying analytical errors. Low totals also characterise the analyses by Grégoire et al. (2000), apparently shifted to lower M values as well, feature which can be related to Ti underestimation, also encountered in our own experience while working on the same type of microprobe (Cameca SX50). Crichtonite minerals (mostly loveringites) from layered intrusions (except for those from the Jimberlana intrusion, referred to later on) appear to be $\mathrm{Fe}^{2+}$-dominant, plotting around the theoretical point, closer in Fig. $6 c$ than in Fig. 6b. Crichtonite minerals from mantle inclusions in kimberlites appear as $\mathrm{Fe}^{3+}$-dominant, in agreement with prevalent $\mathrm{Ce}^{4+}$ over $\mathrm{Ce}^{3+}$ previously assumed, as in Fig. 6c they plot systematically well above the $\mathrm{M}=21$ line, while in Fig. $6 \mathrm{~b}$ form an elongated cluster straddling the theoretical point.

2. Kimberlite-derived crichtonites, besides displaying a high oxidation state of $\mathrm{Fe}$ and $\mathrm{Ce}$, form an array leading from the theoretical $\mathrm{AM}_{21} \mathrm{O}_{38}$ point straight towards $\mathrm{A}_{3} \mathrm{M}_{19} \mathrm{O}_{36}$, in agreement with the views expressed by
Gatehouse et al. $(1978,1983)$ regarding the status of excess large cations. The array is materialized by LIMA analyses of Haggerty et al. (1983), reference mathiasite and landauite, Argyle "KCr-armalcolite" of Jaques et al. (1990) and most of the crichtonite-group analyses of Wang et al. (1999) (Fig. 6b).

3. Crichtonites from hydrothermal veins are as a rule deficient in large cations. As proven by existing Fe valence determinations and correlation of analyses totals with assumed $\mathrm{Fe}$ speciation, they are $\mathrm{Fe}^{3+}$-dominant. Therefore their chemical trend is better approximated in Fig. 6b, being consistent with varying degrees of occupancy in the $\mathrm{M}(0)$ site. The scatter of the points belonging to this group is due to high Fe-contents, leading to important shifts even at low variations in $\mathrm{Fe}^{3+} / \mathrm{Fe}^{2+}$-ratios among individual analyses. The A vs. M correlation excludes elements like $\mathrm{U}, \mathrm{Y}$ and $\mathrm{Th}$ (as is probably also the case of HREE) in the M(0) site, as also asserted by Gatehouse et al. (1979). Of these analyses, as previously claimed by Orlandi et al. (1997), a few qualify for belonging to a distinct mineral species, as they have dominantly vacant $\mathrm{A}$ sites. It is the case of $\mathrm{Pb}$-poor derivatives of senaite - "davidites from Pizzo Cervandone" (Stalder and Bühler, 1987), as well as a partly characterized mineral, not included in our data, described as a new species (romanite, related to davidite) by Drăgilă (1990).

As a summary of the three trends outlined so far, it appears that $\mathrm{Fe}^{2+}$-dominant crichtonites tend to be stoichiometric, while $\mathrm{Fe}^{3+}$-dominant ones display a wide range of large cation contents, describing an array kinked 
exactly in the theoretical $\mathrm{AM}_{21} \mathrm{O}_{38}$ point. Therefore, it results that the contents in large cations is governed in crichtonite minerals by two rules: gradual incorporation of large cations in the $\mathrm{M}(0)$ site until it is filled up and subsequent replacement of the $\mathrm{M}(2)+3 \mathrm{M}(3)$ configuration by additional large cations, while part of the smaller cations adopt a five-fold coordination in square prisms adhering to the new $\mathrm{M}(0 \mathrm{~B}) \mathrm{O}_{12}$ polyhedra.

4. Some compositional outliers are conspicuously not related to the general trend outlined above. Three senaites of Rouse and Peacor (1968) (represented only in Fig. 6c) contain exclusively $\mathrm{Fe}^{2+}$ and display an occupancy of $\mathrm{M}(0)$ by $\mathrm{Pb}$ of around 1 p.f.u. As an alternative to the suggestion of Grey et al. (1976), we propose that divalent iron enters penta-coordinated M(8) (Orlandi et al., 1997) sites, in order to avoid less probable face-sharing with the octahedra in hexagonal rings. Supposed "rattling" of $\mathrm{M}(0)$ cations (Gatehouse et al., 1979) would additionally favour this option. Thus $\mathrm{M}(8)$ sites would be half-occupied for the formula $\mathrm{AM}_{24} \mathrm{O}_{38}$. The mineral exceptionally rich in large cations described by Sarp et al. (1981) probably contains iron in prevalent ferrous state, as suggested by analytical totals. The analyses plot around a point with composition $\mathrm{A}_{1.67} \mathrm{M}_{21} \mathrm{O}_{37.33}$, away from the chemical trend corresponding to large-cation incorporation in $\mathrm{M}(\mathrm{OB})$. At the same time, cell parameters definitely match those of crichtonite group minerals. We suggest that it may also possess a $\mathrm{M}(0 \mathrm{~B})+\mathrm{M}(9)$ configuration, with additional $\mathrm{M}(8)$ prisms as in the previous case. In this interpretation it would lie at one third along the way to fully $\mathrm{M}(0 \mathrm{~B})$-substituted crichtonite with half-occupied $\mathrm{M}(9)$ prisms, or rather its derivative with one third of the $M(8)$ positions also filled, but not far enough to become a new species. Notable Re contents constitute a peculiar feature, but its abundance and probable structural position preclude a new species as well. The material described by Sarp et al. (1981) was reanalyzed by Orlandi et al. (2004), who found no Re and completely different cation abundances. It is still not clear whether the analyses of Orlandi et al. (2004) was conducted on the same material, and the initial WDS microprobe data of Sarp et al. (1981) were in serious and unexplainable error, or the two set analyses characterise two intimately associated phases. Two Jagersfontein "CCZN-armalcolites" (Haggerty, 1983) with relatively low $\mathrm{Fe}$ contents plots near composition $\mathrm{A}_{1.5} \mathrm{M}_{20.25} \mathrm{O}_{37.5}$ (corresponding to $\mathrm{AM}_{13.5} \mathrm{O}_{25}$ ), consistent with additional $\mathrm{T}_{0 \mathrm{~A}}^{6}$ layers in the stacking sequence. Unfortunately no diffraction data exist for these grains. Much of the noise in Figs. 6 b,c is due to the scattered Jimberlana data (Gatehouse et al., 1978; Campbell and Kelly, 1978), plotting as an irregular cloud at high A-values. Jimberlana loveringite-davidite solid solutions display variable, though usually high REE-contents, and the ranges of analyses totals suggest that they might have variable $\mathrm{Fe}^{3+} / \mathrm{Fe}^{2+}$ ratios and also variable $\mathrm{Ce}^{4+} / \mathrm{Ce}^{3+}$, consequential in the $M(0)-M(1)$ distribution of REE. Yet, for consistency reasons and for lack of a better option, they have been recalculated in the same way as the other crichtonites from layered intrusions.

5. A most interesting feature is the distinct clustering of some analyses in both Fig $6 \mathrm{~b}$ and $6 \mathrm{c}$, the bulk of which were described as CCZN-armalcolites. Apart from the overlap with Jimberlana analyses, the cluster consists of one LIMA point (Haggerty et al., 1983), one analysis of "CCZNarmalcolite" from the Jagersfontein kimberlite by Schulze
(1990), inclusions in garnet from the Foltea garnet lherzolite (Săbău et al., 1997) and the Garnet Ridge - Arizona diatreme (Wang et al., 1999), vein minerals in lherzolite nodules of the Kerguelen ocean plateau basalts (Grégoire et al., 2000), and intercumulus phases in the Laouni layered intrusion (Lorand et al., 1987). Except for the two single analyses, all come from occurrences that display a clear split in two populations, one of which approaches stoichiometric crichtonite, while the other is placed in this cluster, with a composition normalized to $\mathrm{A}=1$ of approximately $\mathrm{AM}_{16} \mathrm{O}_{30}$ (see also Figs. 3, 4). Clearly, two structurally different, relatively well-ordered compounds with similar composition, both Ca-dominant, coexist in these occurrences. Typically, in the Garnet Ridge and Laouni occurrence the $\mathrm{AM}_{16} \mathrm{O}_{30}$ compound displays higher $\mathrm{TiO}_{2}$ contents, placed in the field of CCZN-armalcolites of Haggerty (1983). The other two occurrences show uniformly high $\mathrm{TiO}_{2}$ contents of both populations, the differences resulting only from $\mathrm{A} / \mathrm{M} / \mathrm{O}$ ratios and slightly higher $\mathrm{Na}_{2} \mathrm{O}$ contents in the $\mathrm{AM}_{16} \mathrm{O}_{30}$-group (0.6-0.75 vs. $0.15-0.45$ at Foltea and $0.16-0.22$ vs. $0.07-0.14$ in the Kerguelen occurrence). Conspicuously higher $\mathrm{Na}$ was also recorded in the first two occurrences mentioned. The two populations can represent either two loveringite varieties, or loveringite and a different phase. We would rather favor the second option because the $\mathrm{AM}_{16} \mathrm{O}_{30}$-group clusters around a definite composition instead of forming an array that can be related to a compositional shift away from stoichiometric loveringite. Yet, Roentgen diffraction data exist for the Garnet Ridge and Laouni occurrences, in each case the Gandolfi pattern being consistent with a crichtonite group mineral. While for the Laouni occurrence (Lorand et al., 1987) the analyzed grain is similar in composition to analyses plotted around the theoretical crichtonite point, there is no information available about the chemical nature of the grain investigated by Wang et al. (1999). Therefore, the exact nature of the phase clustering around $\mathrm{AM}_{16} \mathrm{O}_{30}$ has still to be ascertained by diffraction data.

\section{A FINAL EDUCATED GUESS: A CANDIDATE FOR THE STRUCTURE OF A-RICH "CCZN-ARMALCOLITES"}

In all occurrences, analytical oxide totals indicate a better fit with prevalent $\mathrm{Fe}^{3+}$ for the $\mathrm{AM}_{16} \mathrm{O}_{30}$ compound (sometimes in conspicuous contrast with $\mathrm{Fe}^{2+}$-dominat loveringites of the same occurrence), also resulting in a better compatibility with the proposed formula and a tighter grouping in Fig. 6b. It is potentially consequential that the $\mathrm{AM}_{16} \mathrm{O}_{30}$ formula matches very well a hypothetical novel type of close-packed oxide structure, based on a triangular pattern (Fig. 7), which would then be intermediate between the magnetoplumbite group, based on single octahedral clusters, and the crichtonite group, based on six-member octahedral clusters. As a topological particularity, the pattern and anti-pattern layers of a triangular cluster-based structure differ by only one octahedral position, and both allow only one other position to which either a tetrahedron or a large cation can be attached. There are five possible layers in the stacking sequence: $\mathrm{T}_{1}^{3}$ (stoichiometry $\mathrm{M}_{8} \mathrm{O}_{16}$ ), $\mathrm{T}^{3}{ }_{1 \mathrm{M}}$ (stoichiometry $\mathrm{M}_{10} \mathrm{O}_{16}$ ), $\mathrm{T}^{3}{ }_{0 \mathrm{~A}}$ (stoichiometry $\mathrm{AM}_{6} \mathrm{O}_{14}$ ), $\mathrm{O}_{\mathrm{A}}^{3}\left(=\mathrm{T}^{3}{ }_{0 \mathrm{AM}}\right.$, stoichiometry $\left.\mathrm{AM}_{8} \mathrm{O}_{14}\right)$ and $\mathrm{O}^{3}$ (stoichiometry $\left.\mathrm{M}_{8} \mathrm{O}_{16}\right)$. The simplest solution for a $\mathrm{AM}_{16} \mathrm{O}_{30}$ compound is a 4-layer (hc. or ACAB) stacking sequence: $\mathrm{O}^{3}{ }_{\mathrm{A}}(\mathrm{h}) \mathrm{T}^{3}{ }_{1}$ (c) 
$\mathrm{T}_{1}^{3}$ (h) $\mathrm{O}^{3}{ }_{\mathrm{A}}$ (c) (Fig. 8). An additional octahedral site $\mathrm{M}(5)$ $\left(\mathrm{T}^{3}{ }_{1 \mathrm{M}}\right.$ instead of $\left.\mathrm{T}^{3}{ }_{1}\right)$, though with low occupancy because it would share faces with both $\mathrm{M}(1)$ and $\mathrm{M}(2)$, could possibly shift the formula towards higher $M$ values p.f.u. By combining stacking symmetry derived by the procedure outlined in Patterson and Kasper (1967) with layer symmetry, this hypothetical compound would be hexagonal, with space group $\mathrm{P} \overline{3}, a \approx 2.88 * \sqrt{7}=7.45 \AA$ and $c \approx 2.3 * 4=$ $9.2 \AA$. From this perspective, structure investigation of A-rich "CCZN-armalcolites" may become both required and rewarding.

As a conclusion, "CCZN-armalcolite" turns out to be no armalcolite at all. The first occurrence cited by Lévy et al. (1972) was indeed a new mineral, loveringite avant la lettre, while similar Ti-rich loveringites have since been found in other occurrences as well.

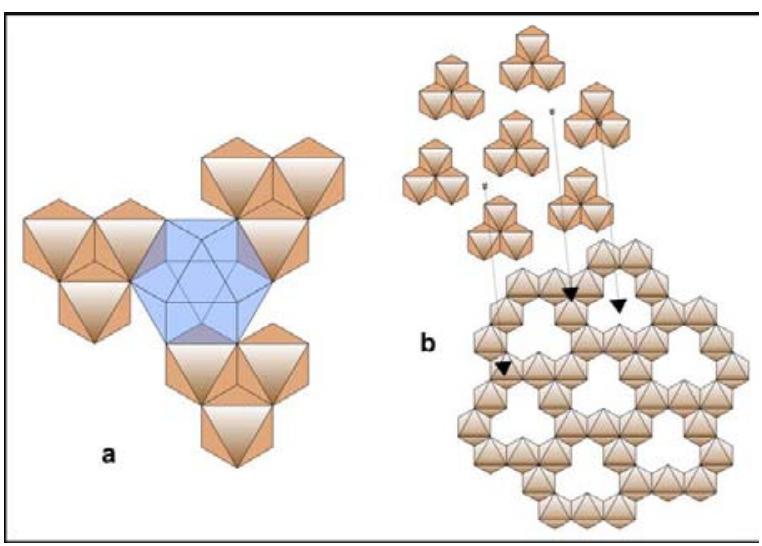

Fig. 7. Particularities of a hypothetical close-packed structure based on triangular clusters (a) The surroundings of the large cation (b) The pattern - anti-pattern structure.

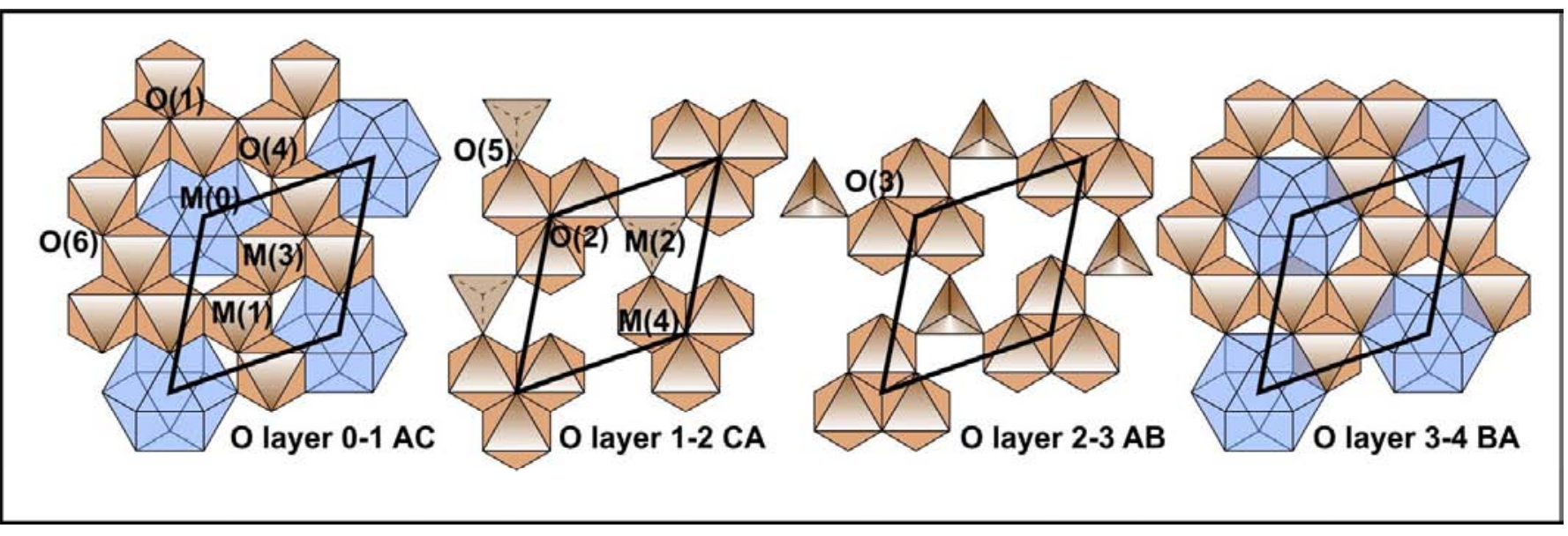

Fig. 8. The simplest stacking sequence involving close-packing of layers based on a triangular pattern. Unit cell, atomic positions, oxygen layers and oxygen stacking outlined.

Large cation - richer "CCZN-armalcolites" with a constant composition identified in several terrestrial occurrences, however, may constitute a term of a new oxide group, also differing from armalcolites and urging to be structurally investigated.

Acknowledgements. This paper resulted from the cooperation of the authors during and subsequent to a NATO-CNR fellowship granted to GS at the University of Turin. Part of the travel expenses related to microprobe work were supported by Grant 1GR/2001 of the Romanian Ministry for Education and Research. Prof. H.-J. Massonne (Institut für Mineralogie und Kristallchemie in Stuttgart) is gratefully acknowledged for allowing and encouraging the access to the analytical devices in his institute.

The authors feel also necessary to acknowledge the contribution of Prof. Mitică Ioane, editor-in-chief of Analele Universității Bucureşti, Secția Geologie, in allowing an extensive period of maturation to an earlier version of the present paper, from the moment it was accepted for publication in the mentioned paper until we decided, a few years later, to withdraw it with better options in view.

\section{R E F E R E N C E S}

Anderson, A.T., Bunch, T.E., Cameron, E.N., Haggerty, S.E., Boyd, F.R., Finger, L.W., James, O.B., Keil, K., Prinz, M., Ramdohr, P. \& El Goresy, A. 1970, Armalcolite: A new mineral from the Apollo 11 samples. Geochimica et Cosmochimica Acta, Supplement 1 (1): 55-63.

Barkov, A.Yu., Pakhomovsky, Y.A., Trofimov, N.N. \& Lavrov, M.M. 1994, Loveringite: a first occurrence in Russia, from the Burakovsky layered intrusion, Karelia. Neues Jahrbuch für Mineralogie, H3: 101-111.

Belluso, E., Castelli, D., Ferraris, G. \& Săbău, G. 1998, TEM identification of microinclusions in pyrope from the Foltea garnet-peridotite (South Carpathians). Plinius, Supplimento italiano dell'European Journal of Mineralogy, 20: 43-44.

Bowles, J.F.W. 1988, Definition and range of composition of naturally occurring minerals with the pseudobrookite structure. American Mineralogist, 73: 1377-1383.

Brigatti, M.F., Contini, S., Capedri, S., Poppi, L. 1993, Crystal chemistry and cation ordering in pseudobrookite and armalcolite from Spanish lamproites. European Journal of Mineralogy, 5: 73-84.

Brown, G.M., Emeleus, C.H., Holland, J.G., Peckett, A. \& Phillips, R. 1972, Mineral-chemical variations in Apollo 14 and Apollo 15 basalts and granitic fractions. Geochimica et Cosmochimica Acta, Supplement 2 (1): 141-157.

Brown, G.M., Peckett, A., Phillips, R. \& Emeleus, C.H. 1973, Mineral-chemical variations in the Apollo 16 magnesio-feldspathic highland rocks. Geochimica et Cosmochimica Acta, Supplement 4 (1): 505-518.

Cabella, R., Gazzotti, M. \& Lucchetti, G. 1997, Loveringite and baddeleyite in layers of chromian spinel from the 
Bracco Ophiolitic Unit, northern Apennines, Italy. Canadian Mineralogist, 35: 899-908.

Cameron, E.N. 1978, An unusual titanium-rich oxide mineral from the Eastern Bushveld Complex. American Mineralogist, 63: 37-39.

Campbell, I.H., Kelly, P. 1978, The geochemistry of loveringite, a uranium-rare earth-bearing accessory phase from the Jimberlana intrusion of western Australia. Mineralogical Magazine, 42: 187-193.

Drăgilă, M. 1990, Observații mineralogice asupra unui nou mineral din grupul daviditului. Revista Minelor, 41(8): 414-418.

Gatehouse, B.M., Grey, I. E., Campbell, I.H. \& Kelly, P.R. 1978, The crystal structure of loveringite - a new member of the crichtonite group. American Mineralogist, 63: 28-36.

Gatehouse, B.M., Grey, I.E. \& Kelly, P.R. 1979, The crystal structure of davidite. American Mineralogist, 64: 1010-1017.

Gatehouse, B.M., Grey, I.E. \& Smyth, J.R. 1983, Structure refinement of mathiasite, $\left(\mathrm{K}_{0.62} \mathrm{Na}_{0.14} \mathrm{Ba}_{0.14} \mathrm{Sr}_{0.10}\right) \mathrm{S}_{1.0}$ $\left[\mathrm{Ti}_{12.90} \mathrm{Cr}_{3.10} \mathrm{Mg}_{1.53} \mathrm{Fe}_{2.15} \mathrm{Zr}_{0.67} \mathrm{Ca}_{0.29}(\mathrm{~V}, \mathrm{Nb}, \mathrm{Al})_{0.36}\right] \mathrm{S}_{21.0} \mathrm{O}_{38}$. Acta Crystallographica, C39: 421-422.

Grégoire, M., Lorand, J.P., O'Reilly, S.Y. \& Cottin, Y. 2000, Armalcolite-bearing, Ti-rich metasomatic assemblages in harzburgitic xenoliths from the Kerguelen Islands: Implications for the oceanic mantle budget of high-field strength elements. Geochimica et Cosmochimica Acta, 64 (4): 673-694.

Grey, I.E., Lloyd, D.J. 1976, The crystal structure of senaite. Acta Crystallographica, B32: 1509-1513.

Grey, I.E. Gatehouse, B.M. 1979, The crystal structure of nigerite-24R. American Mineralogist, 64: 1255-1264.

Grey, I.E., Lloyd, D.J. \& White, J.S. Jr. 1976, The structure of crichtonite and its relationship to senaite. American Mineralogist, 61: 1203-1212.

Haggerty, S.E. 1973, Armalcolite and genetically associated opaque minerals in the lunar samples. Geochimica et Cosmochimica Acta, Supplement 4(1): 777-797.

Haggerty, S.E. 1983, The mineral chemistry of new titanates from the Jagersfontein kimberlite, South Africa: Implications for metasomatism in the upper mantle. Geochimica et Cosmochimica Acta, 47: 1833-1854.

Haggerty, S.E. 1991, Oxide mineralogy of the upper mantle. In Oxide minerals: petrologic and magnetic significance, Reviews in Mineralogy (Lindsley D.H., Ed.), 25: 355-416.

Haggerty, S.E., Smyth, J.R., Erlank A.J., Rickard, R.S. \& Danchin R.V. 1983, Lindsleyite (Ba) and mathiasite (K): two new chromium-titanates in the crichtonite series from the upper mantle. American Mineralogist, 68:494-505.

Hayob, J.L., Essene, E.J. 1995, Armalcolite in crustal paragneiss xenoliths, central Mexico. American Mineralogist, 80: 810-822.

Hey, M.H., Embrey, P.G. \& Fejer, E.E. 1969, Crichtonite, a distinct species. Mineralogical Magazine, 37: 349-355.

Jaques, A.L., O’Neill, H.St.C., Smith, C.B., Moon, J. \& Chapell, B.W. 1990, Diamondiferous peridotite xenoliths from the Argyle (AK1) lamproite pipe, Western Australia. Contributions to Mineralogy and Petrology, 104: 255-276.

Kelly, P.R., Campbell, I.H., Grey, I.E. \& Gatehouse, B.M. 1979, Additional data on loveringite (Ca, REE)(Ti, Fe, $\mathrm{Cr})_{21} \mathrm{O}_{38}$ and mohsite discredited. Canadian Mineralogist, 17: 635-638.
Lévy, C., Christophe-Michel-Lévy, M., Picot, P. \& Caye, R. 1972, A new titanium and zirconium oxide from the Apollo 14 samples. Geochimica et Cosmochimica Acta, Supplement 3 (1): 1115-1120.

Lorand, J.P., Cottin, J.Y. \& Parodi, G.C. 1987, Occurrence and petrological significance of loveringite in the Western Laouni layered complex, Southern Hoggar, Algeria. Canadian Mineralogist, 25: 683-693.

Moore, P.B. 1973, Bracelets and pinwheels: a topologicalgeometrical approach to the calcium orthosilicate and alkali sulfate structures. American Mineralogist, 58: $32-42$.

Moore, P.B., Sen Gupta, P.K. \& Le Page, Y. 1990, Magnetoplumbite $\mathrm{PbFe}_{12} \mathrm{O}_{19}$ : Refinement and lone pair splitting. American Mineralogist, 74: 1186-1194.

Orlandi, P., Pasero, M., Duchi, G. \& Olmi, F. 1997, Dessauite, $(\mathrm{Sr}, \mathrm{Pb})(\mathrm{Y}, \mathrm{U})\left(\mathrm{Ti}_{1} \mathrm{Fe}^{3+}\right)_{20} \mathrm{O}_{38}$, a new mineral from Buca della Vena mine, Tuscany, Italy. American Mineralogist, 82: 807-811.

Orlandi, P., Pasero, M., Rotiroti, N., Olmi, F., Demartin, F. \& Moëlo, Y. 2004, Gramaccioliite-(Y), a new mineral of the crichtonite group from Stura Valley, Piedmont, Italy. European Journal of Mineralogy, 16 (1): 171-175.

Ottreman, J., Frenzel, G. 1965, Der Chemismus der Pseudobrookite von Vulkaniten. Schweizerische Mineralogische und Petrologische Mitteilungen, 45: 819-836.

Pabst, A. 1961, X-ray crystallography of davidite. American Mineralogist, 46: 700-718.

Patterson, A.I., Kasper, S.J. 1967, 7.1 Close packing. In International tables for X-ray crystallography, II: pp. 342-354, Kynoch Press, Birmingham.

Reid, A.M., Warner, J.L., Ridley, W.I. \& Brown, R.W. 1973, Luna 20 soil: abundance and composition of phases in the 45-125 micron fraction. Geochimica et Cosmochimica Acta, 37, 1011-1030.

Rouse, R.C., Peacor, D.R. 1968, The relationship between senaite, magnetoplumbite and davidite. American Mineralogist, 53: 869-879.

Sarp, H., Bertrand, J., Deferne, J. \& Liebich, B.W. 1981, A complex rhenium-rich titanium and iron oxide of the crichtonite-senaite group. Neues Jahrbuch für Mineralogie, Monatshefte, 10: 433-442.

Săbău, G., Castelli, D., Ferraris, G. \& Mărunțiu, M. 1997, Unusual Al-armalcolite and apparently low-symmetry $\mathrm{TiO}_{2}$ inclusions in pyrope from the Foltea garnet peridotite (South Carpathians): some preliminary data and petrological implications. Romanian Journal of Mineralogy 78 (Supplement 1): 87-88.

Schulze, D.J. 1990, Silicate-bearing rutile-dominated nodules from South African kimberlites: metasomatized cumulates. American Mineralogist, 75: 97-104.

Stalder, H.A., Bühler, C. 1987, Geochemische Untersuchungen an Mineralien der Crichtonit-Gruppe aus alpinen Zerrklüfte. Schweizerische Mineralogische und Petrologische Mitteilungen, 67: 93-102.

Steele, I.M. 1974, Ilmenite and armalcolite in Apollo 17 breccias. American Mineralogist, 59: 681-689.

Steele, I.M., Smith J.V. 1972, Occurrence of diopside and Cr-Zr-armalcolite on the Moon. Nature, Physical Sciences, 237: 105-106.

Tarkian, M., Mutanen, T. 1987, Loveringite from the Koitelainen Layered Intrusion, Northern Finland. Mineralogy and Petrology, 37: 37-50. 
Wang, L., Essene, E.J. \& Zhang, Y. 1999, Mineral inclusions in pyrope crystals from Garnet Ridge, Arizona, USA: implications for processes in the upper mantle. Contributions to Mineralogy and Petrology, 135: 164-178.

Wülser, P.-A., Meisser, N., Brugger, J., Schenk, K., Ansermet, S., Bonin, M. \& Bussy, F. 2005, Cleusonite, $(\mathrm{Pb}, \mathrm{Sr})\left(\mathrm{U}^{4+}, \mathrm{U}^{6+}\right)\left(\mathrm{Fe}^{2+}, \mathrm{Zn}\right)_{2}\left(\mathrm{Ti}_{1} \mathrm{Fe}^{2+}, \mathrm{Fe}^{3+}\right)_{18}(\mathrm{O}, \mathrm{OH})_{38}$, a new mineral species of the crichtonite group from the western Swiss Alps. European Journal of Mineralogy, 17 (6): 933-942. 